\title{
Evaluation of Population Structure and Genetic Diversity of Cirrhinus mrigala among the Different Freshwater Rivers of Pakistan Using Molecular Marker: Study Implications and Its Importance in Aquaculture
}

\author{
Muhammad Naeem $^{1^{*}}$, Samrah Masud ${ }^{1}$, Zara Naeem $^{1}$, Ammar Danyal Naeem $^{1}$, \\ Muhammad Khalid ${ }^{2}$ and Shoaib Hassan ${ }^{1}$ \\ ${ }^{1}$ Institute of Pure and Applied Biology, Bahauddin Zakariya University, Multan, Pakistan. \\ ${ }^{2}$ Govt. Emerson College, Multan, Pakistan.
}

\begin{abstract}
Authors' contributions
This work was carried out in collaboration among all authors. Author MN designed the study, performed the statistical analysis, wrote the protocol and wrote the first draft of the manuscript. Authors MN and SH managed the analyses of the study. All authors read and approved the final

manuscript.

Article Information

DOI: $10.9734 / A R R B / 2020 / v 35 i 730242$

Editor(s):

(1) Dr. Md. Aminur Rahman, Jashore University of Science and Technology, Bangladesh.

Reviewers:

(1) R. Uma Maheswari, Arulmigu Palaniandavar Arts College for Women, India. (2) Tiogué Tekounegning Claudine, The University of Dschang, Cameroon. Complete Peer review History: http://www.sdiarticle4.com/review-history/56666
\end{abstract}

Original Research Article

Received 04 March 2020

Accepted 10 May 2020

Published 27 July 2020

\section{ABSTRACT}

Cirrhinus mrigala (Family Cyprinidae) have vast presence in different studied rivers of Pakistan. Present study was designed to formulate the genetic diversity of desired sites in Cirrhinus mrigala populations using nine Random amplified polymorphic DNA markers. Total hundred individuals were used to conduct this study and were collected from three distinct rivers (River Indus, Chenab and Ravi) with four specified sites with wild of Pakistan were used to study. A random Amplified Polymorphic DNA primer analyzes various bands of polymorphic loci. Mean genetic diversity within and between populations found $81.53 \%$ and $2.27 \%$ respectively by using analysis of molecular variance. Fixation index was found variably and Pairwise $F_{\mathrm{st}}$ analysis showed significant difference between different sites of studied populations. Genetic divergence information would mark 
essential in order to improve genetic programming its management and conservation of natural inhabitation. In order to quantify the study of population divergence by using these molecular markers is an efficient way to pin point the genetic diversity within and among population.

Keywords: Genetic diversity; freshwater; fishes; rivers; molecular markers.

\section{INTRODUCTION}

Freshwater fishes marked as very diverse group relatively but have a significant freshwater habitat globally, also named for globally most endangered group [1]. Cultivable freshwater fish Cirrhinus mrigala belongs from family Cyprinidae. Cirrhinus mrigala have presence in major river systems of subcontinent. In India, it is locally cultivated along with other species of carps in polyculture system. Comparatively rapid expansion was found up to 1996, and till 2003 total global mrigal production remain constant [2]. However, declining trend was found comparatively from 1958 to 1994 [3]. Wild populations of major carps mark at risk; because of loss in genetic variability and diversity, due to decline in genetically diverse wild stock also it mixing [4]. Natural stock variability provided basis for breeding selection. So, to understand the genetic variability would be helpful for setting up of genetic improvement. DNA markers have significant importance use in different cultured fish species assess the level and pattern of genetic diversity [5]. Genetic diversity acts a tool for the assessment of genotypic variety present in species, group of specie and population [6]. Information about genetic structure and polymorphism in species and subspecies of fishes extensively used in management of aquatic genetical resources [7]. Activities are credentials for genetic resources and variety of ecosystems; characterization determine the genetic structure, evaluation that estimate economic potential [8]. Molecular approach by Microsatellite markers used to provide valuable information for genetic conservation and management of several freshwater species [9]. Microsatellite marker is one of useful technique for molecular biologists to analyze the population structure and allelic diversity and extensive array of applications in study of population genetics and variation in the species with little expenditure, time and effort [10].

\section{MATERIALS AND METHODS}

A total of 100 samples (equal in each case) of Cirrhinus mrigala populations were intended to study. Samples were collected from four wild population sites, Head Taunsa (site 1), Toba Tek Singh (site 2) and Fateh-Pur Jhung (site 3), and from Muzaffargarh, Pakistan (site 4). Sampled populations detail is presented in Table 1 and sites are also indicated in Fig. 1. DNA extracted from various tissues (caudal fin, pectoral fin, pelvic fin, muscle and gills) using modified phenol-chloroform method.

Samples of various organs (Caudal fin, Pectoral fin, Pelvic fin, Muscle and Gills) were taken for the extraction of DNA, Samples of muscle tissue were excised from the lateral muscle (skin removed) on the right side of the fish specimens and were minced with sterile razor blades prior to DNA extraction.

DNA was isolated from samples of various organs (Caudal fin, Pectoral fin, Pelvic fin, Muscle and Gills) were taken for the extraction of DNA. Tissue size was of $50-100 \mathrm{mg}$ with 600$800 \mu \mathrm{l}$ extraction buffers for grinding. $12 \mu \mathrm{l}$ Proteinase $\mathrm{K}$ been was added, vortex it and incubated at $37^{\circ} \mathrm{C}$ and $55^{\circ} \mathrm{C}$ for $1 \mathrm{hr}$ respectively each. Solution was centrifuged, then supernatant was collected and equal volume of phenol: chloroform: isoamyl alcohol, mixed gently and again centrifuged. Supernatant was collected, added 0.1 volume of $3 \mathrm{M}$ sodium acetate and equal volume of pure ethanol. Placed at $-20^{\circ} \mathrm{C}$ for 1-2 $\mathrm{hr}$ and then centrifuged it again, wash it and stored at $-20^{\circ} \mathrm{C}$ until further analyses.

Impurities in the diluted DNA were quantified by measuring absorbance at 260/280nm with the help of nanophotometer (IMPLEN). The integrity of DNA was checked by loading $5 \mu$ l of isolated DNA, $2 \mu \mathrm{l}$ DNA loading dye on $0.8 \%$ agarose gel stained. Isolated DNA was also quantified by direct comparison with $1 \mathrm{~Kb}$ standard marker (GeneON).

Polymerase chain reaction for amplification of genomic DNA by using different primers to analyze the genetic diversity. To make PCR solution $4.5 \mu \mathrm{l}$ of master mix (dNTP's, $\mathrm{MgCl}_{2}$, Tag Polymerase; BioShop, Canada Inc.), $19.4 \mu \mathrm{l}$ water, $0.1 \mu \mathrm{l}$ DNA template were mixed in PCR tubes. PCR amplification was carried out in Labcycler (SENSQUEST, Germany), comprising pre-denaturation at $95^{\circ} \mathrm{C}$ for $5 \mathrm{~min}$ followed by 40 cycles, denaturation, annealing and extension were at $95^{\circ} \mathrm{C}, 36^{\circ} \mathrm{C}$ and $72^{\circ} \mathrm{C}$ respectively for 1 min, with final extension at $72^{\circ} \mathrm{C}$ for $10 \mathrm{~min}$. 
Table 1. Various parameter their sites, location, numbers and types of Cirrhinusmrigala

\begin{tabular}{|c|c|c|c|c|c|c|}
\hline Population & Sites & Types of population & Location for sampling & $\begin{array}{l}\text { Coordinate (latitudes } \\
\text { and longitudes) }\end{array}$ & Date of Sampling & $\begin{array}{l}\text { Number of } \\
\text { samples }\end{array}$ \\
\hline Cirrhinus mrigala & FatehpurJhang & Wild & Chenab River & $31^{0} 28^{\prime} \mathrm{N} 72^{0} 32^{\prime} \mathrm{E}$ & 02 Oct. 2018 & 25 \\
\hline Cirrhinus mrigala & Head Taunsa & Wild & Indus River & $30^{\circ} 42^{\prime} \mathrm{N} 070^{\circ} 50^{\prime} \mathrm{E}$ & 24 Dec. 2018 & 25 \\
\hline Cirrhinus mrigala & Toba Teksingh & Wild & Ravi River & $30^{\circ} 45^{\prime} \mathrm{N} 72^{\circ} 57^{\prime} \mathrm{E}$ & 10 Oct. 2018 & 25 \\
\hline Cirrhinus mrigala & Muzaffargarh & Wild & Chenab River site Pond & $30^{\circ} 4^{\prime} 27^{\prime} \mathrm{N} 71^{\circ} 11^{\prime} 4 \mathrm{E}$ & 26 Dec. 2018 & 25 \\
\hline
\end{tabular}


For control region sequencing with set of RAPD, primer was used for PCR amplification. After amplification, the polymerase chain reaction products were run on $1 \%$ gel for $1 \mathrm{hr}$. Diversity were noted on gel document and saved it to analyze genetic diversity. Primer sequences of randomly amplified polymorphic DNA markers were used in this study are shown in Table 2.

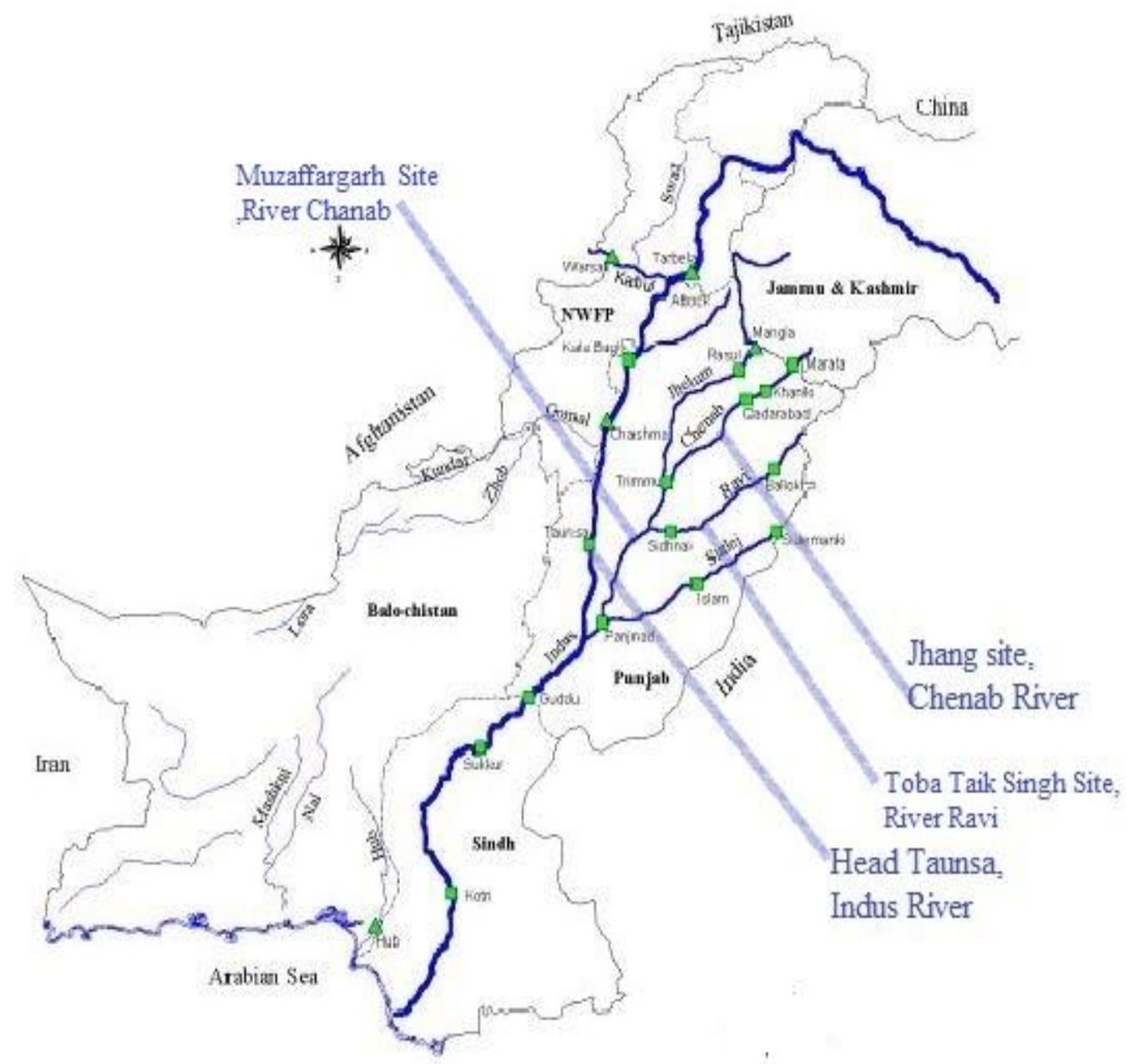

Fig. 1. Sampling sites of Cirrhinus mrigala from different rivers of Pakistan

Table 2. Primer sequences of randomly amplified polymorphic DNA markers used in this study

\begin{tabular}{lllllll}
\hline Primer & Sequence (5' $\rightarrow$ 3') $^{\prime}$ & DD & MW & Tm & Nmol & GC content \% \\
\hline OPA-01 & 5' ACTGGGTCGG 3' & 3.7 & 3.084 & $34^{\circ} \mathrm{C}$ & 34 & 70 \\
OPA-04 & 5' AATCGGGCTG 3' & 3.8 & 3.068 & $32^{\circ} \mathrm{C}$ & 34 & 60 \\
OPB-03 & 5' AGGGTCGGTC 3' & 3.7 & 3.084 & $34^{\circ} \mathrm{C}$ & 34 & 70 \\
OPN -11 & 5' AAAGCTGCGG 3' & 4 & 3.077 & $32^{\circ} \mathrm{C}$ & 34 & 60 \\
OPA-09 & 5' GGGTAACGCC 3' & 3.7 & 3.053 & $34^{\circ} \mathrm{C}$ & 34 & 70 \\
OPA-14 & 5' CCGAGCACCG 3' & 3.5 & 2.998 & $36^{\circ} \mathrm{C}$ & 34 & 80 \\
FA-8 & 5' AGTCAGCCAC 3' & 3.7 & 4.997 & $32^{\circ} \mathrm{C}$ & 34 & 60 \\
R-1 & 5' CACCCCCTTG 3' & 3.1 & 2.924 & $34^{\circ} \mathrm{C}$ & 34 & 70 \\
\hline
\end{tabular}




\subsection{Statistical Analysis}

Genetic polymorphism can also be noted loci, Nei's Gene Diversity Index [11]. Nei's genetic distances between populations [12], (POPGENE) were used to construct (UPGMA) unweighted pair group method arithmetic average dendrograms in NTSYSpc 2.11 after [13]. Genetic diversity $(\mathrm{H})$ was calculated at two levels: the average diversity within populations and the total diversity. An analysis of molecular variance (AMOVA) was performed using Arlequin [14], and analyzed within and among populations. The pair wise fixation index $\left(F_{S T}\right)$ was used to evaluate the level of genetic differentiation among populations. Sequential Bonferroni corrections [15] were used to correct for multiple testing.

\section{RESULTS}

Nine total primers and forty five primers in combination with each other were tested in this study. Primers (OPA-1, OPA-2, OPB-3, OPN-11, OPA-9, OPA-14, FA-8, R-1 and OPB-11) showed different polymorphic bands. Each primer showed a variable number of banding. A multiple banding was formed after analyzing. Almost 3,4 band was formed in each primer sequence individually, multiple banding was formed in case of multiple primer, also had differ banding pattern variable to site of selection and nature of that fish varies in case of wild from various sites. 112 bands were detected totally, a diverse polymorphism were formed.

Cirrhinus mrigala from four different sites of three rivers from Pakistan, under wild system were used to mark genetic diversity. Variable numbers of polymorphic band were found in the studies fish species from various sites and maximum number of polymorphic band were observed 25 form river Indus, Head Taunsa site and minimum number of band were observed in 14 in Toba Tek Singh site, River Ravi. Nei's gene diversity was mentioned in Table 3. Nei's genetic distances between all of the populations 0.3815 .45 (FatehJhang site), 0.4640 .48 (Head Taunsa site), 0.2265.44 (Toba Tek Singh site) and 0.3165.45 (Muzaffargarh site) mentioned in Table 3.

Randomly amplified polymorphic DNA markers marked high degree of genetical differentiation among selected specified site of various site in Cirrhinus mrigala. Significant relation through variance found I n?? all the site marked significant diversity among each other within a group and among the group, highly significant effect were found in values $0.34,0.238,0.014$ and 0.013 in geographical wild populations of River Chenab, head taunsa (Indus River), Toba Teksingh (River Ravi) and Muzaffargarh site (River Chenab) respectively. Frequencies of Genotypic differences found significant among all of the populations (Table 4).

Genetic diversity indicated $2.27 \%$ variation explicate among population, whereas $81.53 \%$ variation found within individual population using analysis of molecular variance through significant fixation index (Table 5). Neighbourhood joining tree constructed based on divergence showed populations were grouped into two clusters. These cluster based on geographically close group of population. $F_{\mathrm{ST}}$, AMOVA and Neighborhood Joining tree was used to analyze degree of genetic differentiation between various site populations of different river in Pakistan.

Table 3. Polymorphic bands and Nei's gene diversity of different population sites

\begin{tabular}{lllll}
\hline & \multicolumn{3}{l}{ Population } \\
\hline Parameter & $\begin{array}{l}\text { Fateh Jhang } \\
\text { site }\end{array}$ & $\begin{array}{l}\text { Head Taunsa } \\
\text { site }\end{array}$ & $\begin{array}{l}\text { Toba Tek } \\
\text { Singh site }\end{array}$ & Muzaffargarh Site \\
\hline Polymorphic bands & 22 & 25 & 14 & 16 \\
Nei's gene diversity & 0.3815 .45 & 0.4640 .48 & 0.2265 .44 & 0.3165 .45 \\
\hline
\end{tabular}

Table 4. Analysis of variance among various sites of Cirrhinus mrigala

\begin{tabular}{lllllll}
\hline \multicolumn{7}{c}{ Analysis of variance ( ANOVA) } \\
\hline & \multicolumn{2}{c}{ Cluster } & \multicolumn{2}{c}{ Error } & F & \multirow{2}{*}{ Sig. } \\
\cline { 2 - 6 } & Mean Square & Df & Mean Square & Df & & \\
\hline FatehPurJhung site & 3.756 & 1 & .543 & 7 & 6.918 & $.034^{* * *}$ \\
Indus Site & .939 & 1 & .564 & 7 & 1.664 & $.238^{* * *}$ \\
Toba teksingh Site & 5.339 & 1 & .507 & 7 & 10.527 & $.014^{* * *}$ \\
MUzaffargarh Site & 2.450 & 1 & .221 & 7 & 11.065 & $.013^{* *}$ \\
\hline
\end{tabular}


Table 5. Analysis of molecular variance of randomly amplified polymorphic DNA primer in Cirrhinus mrigala

\begin{tabular}{lllllll}
\hline Source of variation & Df & $\begin{array}{l}\text { Sum of } \\
\text { squares }\end{array}$ & $\begin{array}{l}\text { Variance } \\
\text { components }\end{array}$ & $\begin{array}{l}\text { Percentage } \\
\text { of variation }\end{array}$ & $\begin{array}{l}\text { Fixation } \\
\text { Index }\end{array}$ & $\begin{array}{l}\text { P } \\
\text { Value }\end{array}$ \\
\hline Among populations & 3 & 2.814 & 0.01170 & 2.27 & 0.024 & .038 \\
Within populations & 119 & 58.947 & 0.46273 & 81.53 & & \\
Total & 124 & 62.761 & 0.47443 & & & \\
\hline
\end{tabular}

Table 6. Pairwise $\mathrm{F}^{\text {st }}$ amongs four riverine populations of Cirrhinus mrigala

\begin{tabular}{lllll}
\hline Fish Population Site & $\begin{array}{l}\text { Fatehpur } \\
\text { Jhung }\end{array}$ & Head Taunsa & Toba Teksingh & Muzaffargarh \\
\hline FatehpurJhung & 0.014 & $0.792^{\star * *}$ & $0.693^{\star * *}$ & 0.00 \\
Head Taunsa & 0.028 & 0.020 & $0.549^{* * *}$ & $0.054^{\star * *}$ \\
Toba Teksingh & 0.024 & 0.009 & 0.009 & 0.009 \\
Muzaffargarh & $0.139^{\star * *}$ & $0.057^{\star * *}$ & $0.074^{\star * *}$ & 0.046 \\
\hline
\end{tabular}

$F_{\text {st }}$ values found in studied populations ranges from 0.00 to $0.792(p<.05)$, from lower to higher marked. Highest found pair wise value of $F_{\text {st }}$ observed among population of Muzaffargarh and Fatehjhung shows lowest value, these variable values from various site also named as a genetically differentiation in studied site population (Table 6).

\section{DISCUSSION}

Randomly Amplified Polymorphic DNA PCR method is a powerful tool for genetic marker assessment of molecular markers $[16,17]$ confirmed by the results of the present study because, for all primers, different banding patterns were observed within and between the species.

A low level of genetic variation was observed in the fish stock collected from four different locations. As mentioned varying diversity in fish stocks. The loss in genetic variation in the fish stocks of $O$. niloticus in Wadi Haneffah, Riyadh, Saudi Arabia due to increased load of domestic and industrial waste. The increasing loss in the genetic variation in the tilapia may decrease its potential to overcome the habitat degradation due to anthropogenic activities. Ecosystem has complete dependence upon their diversity inside [18]. Interaction among number of species of habitat in an aquatic ecosystem may direct to uphold composition structure of fish fauna [19]. Biodiversity were found higher than already studied. Biodiversity of fish fauna marked its support for genetic diversity as it is increasing frequently.

By using three indices to measure the intensity of genetic diversity including polymorphic bands numbers, variation within and between population and Nei's gene diversity almost showed a similar order in all four populations. Study indicated diversity in all organisms observed highest genetic diversity level in site 1 (Head Taunsa) population as suggested by $\mathrm{Li}$ et al. [20]. Randomly amplified polymorphic DNA markers steadily was used in order to analyze the population structure, individual within and in between population estimation for genetic variation in different species groups [21].

Randomly amplified polymorphic DNA analysis effectively seconds his importance in research especially in the field of fisheries to point out genetic diversity present at subspecies, species and population levels as in Poecili areticulata [22]; Micropteruss almoides [23]; Salmo salar, Salmo trutta and Labeo rohita [24]; Cyprinus carpio [25] and Icta lurid catfishes [26] respectively. Same technique was also followed in the present study which was aimed to study the genetic diversity of Cirrhinus mirigala, collected from three different rivers of Pakistan. Genetic variation detected because of gene flow result also seemed to be similar as C. mrigala populations from the Gangetic region [27].

Amplification through a number of Randomly amplified polymorphic DNA markers in four different populations of Cirrhinus mrigala and a higher degree of polymorphism at loci put forwarded Currently exploited condition and randomly amplified polymorphic DNA makers comprises sufficient potential means to make a distinction among different geographically or genetically isolated populations and also confirm locally adapted populations existence. Remarkable differences frequencies or pattern of 
band in C. mrigala populations of various sites from different Rivers indicating good biased potentials of studied markers as previously reported among the different populations of the freshwater fish species [28].

Amplification patterns through randomly amplified polymorphic DNA markers used for comparison within and between populations of Cirrhinus mrigala in present study. Size and fragments numbers generally depends upon nucleotide sequence in primer and as DNA template source, therefore resultant of that fragment in specified random DNA fingerprinting [29]. Present study also showed considerable genetic variation among populations.

Similar studies using randomly amplified polymorphic DNA marker in Prochilodus marggravii and Tachysurus fulvidraco [30] have showed a significantly variation in various population from different localities and ecological isolation. In case of cultured population's levels of genetic diversity found lower wild populations. Results are in agreement with Micropterus salmoides and Larimichthys crocea [31], followed to that have consistent have known impact on hatchery based population [32].

$\mathrm{F}_{\mathrm{ST}}$ comparison is also used a measure by mean of differentiation within and between population as an important insight in case of evolutionary process result in genetic differentiation [33]. $\mathrm{F}_{\mathrm{ST}}$ magnitude values are to 0 to 0.05 stands for little differentiation, $0.05-0.25$ for moderate and higher than 0.25 resultant of higher differentiation among populations [34]. Present study indicated differentiation variably form 0 to 0.792 . Highest 0.792 found in between site 1 and site 3 , indicating rapid genetically differentiation be achieved between wild population. Analysis of molecular variance showed 2.27 and $81.53 \%$ variation between and within populations. Variance within and between populations was $\left(F_{s t} 0.024\right)$. Analysis of molecular variance thus suggested considerably higher variances put individual variation present within populations than between population. Pairwise $F_{\text {st }}$ estimation for all of loci was found 0-0.792 among population. So the similar form of result for genetic variation were noticed in the Kelantan population, showed higher degree of differentiation amongst populations $F$ st was found ranges from 0.1811 to 0.6494 [35].

Similarly, the results of genetic distances based on un-weighted Pair Group Method with
Arithmetic Mean analysis (UPGMA) exploiting nine randomly amplified polymorphic DNA markers separated into two clusters. Four populations of three river constituted cluster of one population formed the second sub-group. Population found variable genetic distance. Findings were also confirmed by Chatta and Ayub [36].

\section{CONCLUSION}

This study curried to investigate the genetic variation in species by using different random primers in RAPD analysis. It has been concluded that RAPD technique is very useful to collect data about the genetic variation in the wild stock of fish population. This information may be helpful to plan strategies for improvement in the breeding program by the fisheries biologist.

Randomly amplified polymorphic DNA marker is useful in order to study population divergence. Randomly amplified polymorphic DNA markers, with a higher number of genetic diversity that work more efficiently in analysis differences within or between that population. Sufficient genetic diversity marked in studied area of river from various sites in the individual population and in different populations remarkably isolated from each other this will also cause immediate problem for future survival of $C$. mrigala in the area. Not only reservoirs, pollution or dams caused effective population isolations but also river systems probably break such isolations. Four populations collected from different rivers and sites of Pakistan noticed frequent inter and intra-population movements of individuals.

\section{ETHICAL APPROVAL}

As per international standard written ethical permission has been collected and preserved by the author(s).

\section{COMPETING INTERESTS}

Authors have declared that no competing interests exist.

\section{REFERENCES}

1. Cooke SJLapointe NWR, Martins EG, Thiem JD, Raby GD. Failure to engage the public in issues related to inland fishes and fisheries: Strategies for building public and political will to promote meaningful 
conservation. Journal of Fish Biology. 2013;83:997-1018.

2. FAO. Fishstat plus: Universal software for fish statistics time series, version 2.3 2000. FAO; Fisheries department, Fisheries information, data and satistical unit [Internet]; 2006.

3. Payne Al, Sinha R, Singh HR, Huq SA. Review of Ganges basin: Its fish and fisheries. In: Welcomme R, Petr T, editors. Proceedings of the second International Symposium on the Management of Large Rivers for Fisheries. Sustaining Livelihoods and Biodiversity in the New Millennium. FAO Regional Office for Asia and the Pacific, Bangkok, Thailand. 2004;16(1).

4. Reddy PVGK. Carp genetic resources of India, carp genetic resources for aquaculture in Asia. Malaysia: World Fish Center publishing Inc. 2005;39-53.

5. Liu ZJ, Cordes JF. DNA marker technologies and their applications in aquaculture genetics. Aquaculture. 2004; 238:1-37.

6. Rez Â, Bautista AM, Almodo ANA, Machordom A. Evolution of the mitochondrial control region in Palaearctic brown trout (Salmo trutta) populations. 2001;87:198-206.

7. Saad YM, Ali SF, Hanafi MS, Ezza MA, Guerges AA. Genetic signature of some Egyptian Clarias gariepinus Populations. Global Vet. 2009;3:503-508.

8. Nandani K, Thakur SK. Randomly amplified polymorphic DNA a brief review. American Journal of Animal and Veterinary Sciences. 2014;9:6-13.

9. Wasko AP, Martins C, Oliveira C, Senhorini JA, Foresti F. Genetic monitoring of the Amazonian fish matrincha (Bryconcephalus) using RAPD markers: Insights into supportive breeding and conservation programmes. Journal of Applied Ichthyology. 2004; 20:48-52.

10. Zohar $\mathrm{Y}$, Hines $\mathrm{AH}$, Zmora $\mathrm{O}$, Johnson EG, Lipcius RN, Seitz RD, Eggleston DB, Place AR, Schot TEJ, Stubblefield JD, Chung JS. The Chesapeake Bay Blue Crab (Callinectes sapidus): A Multidisciplinary Approach to Responsible Stock Replenishment. Reviews in Fisheries Science. 2008;16:24-34.

11. Nei M. Genetic distance between populations. Am Natural. 1973;106:283292.
12. Nei M. Estimation of average heterozygosity and genetic distance from a small number of individuals, Genetics. 1978;89:583-590.

13. McKinnon JS, Mori S, Blackman BK, Lior D. Evidence for ecology's role in speciation. Nature. 2004;429:294-298.

14. Schneider S, Roessli D, Excoffier L. Arlequin: A software for population genetics data analysis. Geneva, Switzerland: Genetics and Biometry Laboratory, Department of Anthropology, University of Geneva; 2000.

15. Rice WR. Analyzing tables of statistical tests. Evolution. 1989;43:223-225.

16. Baradakci F, Skibinski DOF. Application of the RAPD technique in Tilapia fish: species and subspecies identification. Herditary. 1984;73:117-123.

17. Naish KA, Warren M, Bardacki F, Skibinski DOF, Carvalho GR, Mair GC. Multilocus DNA fingerprinting and RAPD reveal similar genetic relationships between strains of Orechromis niloticus (Pisces: Cichlidae). Molecular Ecology. 1994;4:71274.

18. Elmqvist T, Folke C, Nystrom M, Peterson $\mathrm{G}$, Bengtsson J, Walker $\mathrm{B}$, Jon $\mathrm{N}$. Response diversity, ecosystem change, and resilience. Frontiers in Ecological Environment. 2003;9:488-494.

19. Agnisto A, Thomas S, Gomes L. Conservation of the biodiversity of Brazil's inland waters. Conservation Biology. 2005; 19:646-652.

DOI:http://dx.doi. org/10.1111/j.15231739.2005.00701.x

20. Li SF, Cai WQ, Zhou BY. Morphology and biochemical genetic variations among populations of blunt snout bream (Mega lobramaamblycephala). Journal of China Fisheries. 2009.15;204-211.

Available:https://www.ncbi.nlm.nih.gov/pub $\mathrm{med} / 28535200$.

21. Wolf JBW, Bayer T, Haubold B, Schilhabel M. Nucleotide divergence vs gene expression differentiation: Comparative transcriptome sequencing in natural isolates from the carrion crow and its hybrid zone with the hooded crow. 2010; 19:162-175.

22. Suresh E, Tiwari VK, Sekar M, Sankar M, Kathirvelpandian A. Genetic structure of populations of Mugilcephalus using RAPD markers. African Journal of Biotechnology. 2013;12(44):6262-6266. 
23. WangJT, Li JT, Zhang XF, Sun XW. Transcriptome analysis reveals the time of the fourth round of genome duplication in common carp (Cyprinu scarpio). BMC genomics. 2012;13(1):96.

24. Parveen JE, Thangaraj M, Kumar TTA, Bhimba BV, Rajasekar M. RAPD Probe on Genetic Variation in Damselfishes (Family Pomacentridae) in Gulf of Mannar Region. Asian Journal of Experimental Biology Science. 2011;2(4):687-690.

25. Chiu T, Su Y, Lin H, Hsu C. Molecular Electrophoretic Technique for Authentication of the Fish Genetic Diversity, 2009.

ISBN978-953-51-0457-5

Available:http://cdn.intechopen.com/pdfs/3 4913/InTech

26. Gjedrem T, Baranski M. Selective Breeding in Aquaculture: An Introduction. In Reviews: Methods and Technologies in Fish Bio and Fish; 2009.

Available:https://www.springer.com/gp/boo k/9789048127726

27. Chauhan T, Lal KK, Mohindra Singh VRK, Punia P, Gopalakrishnan A, Sharma PC, Lakra WS. Evaluating genetic differentiation in wild populations of the Indian major carp, Cirhinus mrigala (Hamilton-Buchanan, 182): Evidence from alozyme and microsatellite markers. Aquaculture. 2007;269:135149.

28. Sanches A, Gelleti PM, Galzerani JRF, Derazo J, Cutilak-bianchi B, Hatanaka T. Genetic population structure of two migratory fresh water ish species (Bryconorthotaenia and Prochilodus argenteus) from the São Francisco River in Brazil. 2012;40(1):177-186.
29. Welsh J, McClelland M. Finger printing genomes using PCR with arbitrary primers. Nucleic Acids: Research. 1990;18:72137218.

30. Hatanaka TPM, Galletti JR. RAPD markers indicate the occurrence of structured population in a migratory fresh water fish species, Sao Paulo. Genetic and Molecular Biology. 2003;26(1).

31. Liang SX, Sun XW, Bai JJ, Gao JS. Genetic analysis for cultured largemouth bass (Micropterus salmoides) in China with microsatellites. Acta Hydrobiol Sin. 2008; 32:694-700.

32. Ariki $H$, Schmid C.Is hatchery stocking a help or harm? Evidence, limitations and future directions in ecological and genetic surveys. Aquaculture. 2010;308:2-11.

33. Holsinger KE, Weir BS. Genetics in geographically structured populations: Defining, estimating and interpreting FST. Natural Review of Genetics. 2009;10(9): 639-650.

Available:https://www.ncbi.nlm.nih.gov/pm c/articles/PMC4687486/

34. Wright S. Evolution and the genetics of populations, Vol. 4: variability within and among natural populations. Chicago: The University of Chicago Press; 1978.

35. Esa Y, Rahim KAA. Genetic structure and preliminary findings of cryptic diversity of the Malaysian Mahseer (Tor tambroides Valenciennes: Cyprinidae) Inferred from Mitochondrial DNA and Microsatellite Analyses. BioMedical Research International. 2013;14.

36. Chatta AM, Ayub M. Growth performance of hatchery reared Golden mahseer (Tor macrolepis) at Sialkot, Pakistan. 2010; 56:1-8.

(c) 2020 Naeem et al.; This is an Open Access article distributed under the terms of the Creative Commons Attribution License (http://creativecommons.org/licenses/by/4.0), which permits unrestricted use, distribution, and reproduction in any medium, provided the original work is properly cited.

Peer-review history:

The peer review history for this paper can be accessed here: http://www.sdiarticle4.com/review-history/56666 